\title{
Notes on rare and threatened flora in western-central Iberia
}

\author{
Rubén Ramírez-Rodríguez \& Francisco Amich (*)
}

\begin{abstract}
Ramírez-Rodríguez, R. \& Amich, F. Notes on rare and threatened flora in western-central Iberia. Lazaroa 35: $221-226$ (2014).

Here we provide new records for the Natural Park of Las Arribes del Duero (Salamanca-Zamora) regarding six rare and endangered plants in western central Iberia. We also discuss different aspects from the point of view of conservation and the current status of new populations.
\end{abstract}

Keywords: Threatened flora, Plants Species, Arribes del Duero, Salamanca, Spain.

Resumen: Ramírez-Rodríguez, R. \& Amich, F. Notas sobre flora rara y amenazada en el centro occidente ibérico. Lazaroa 35: 221-226 (2014).

Aportamos nuevas localidades en el Parque Natural de Las Arribes del Duero (Salamanca-Zamora) para 6 plantas raras y amenazadas del centro occidente ibérico. Comentamos asimismo diferentes aspectos desde el punto de vista de la conservación y estado actual de las nuevas poblaciones.

Palabras clave: flora amenazada, Arribes del Duero, Salamanca, España.

\section{INTRODUCTION}

The Natural Park in the Arribes del Duero (Lusi$\tan$ Duriensean biogeographic sector, Carpetano-Leonesa subprovince, Western Iberian Mediterranean province, RIVAS-MARTíNEZ 2002) has an extension of $170.000 \mathrm{Ha}$, unequally distributed throughout the provinces of Salamanca and Zamora, and it extends along the banks of the Duero River and some of its main tributary rivers (Águeda, Huebra and Uces).

Regarding the vegetation, these territories are characterized by climatophilous meso-forests of the Genisto hystricis-Quercetum rotundifoliae and Junipero lagunae-Quercetum suberis associations, and climatophilous and edafoxerophilous forests of the Rusco aculeati-Juniperetum lagunae association (Rivas-Martínez, 2011, Costa \& al. 2012). The main lithological, geomorphological, bioclimatic and ethnobotanical characteristics of the zone were described by AMICH \& al. (2004), BERNARDOS \& al. (2004b) and GONZÁLEZ \& al. (2012).
The references materials are deposited in the Herbarium of the University of Salamanca (SALA). For each citation, the following data are provided: locality, $1 \mathrm{~km}$ x $1 \mathrm{~km}$ UTM coordinates, altitude, ecology and plant communities in which it is integrated, the data of collection and the names of the collectors.

For the nomenclature and authorship of the taxa and syntaxa, we followed Flora Iberica (CASTROVIEJO, 1986-2012) and RIVAS-MARTíNEZ (2011) and COSTA \& al. (2012). We indicate the taxa included in the Red List of Spanish Vascular Flora (henceforth RL2008, MoRENO, 2008) and/or in the Decree of Protected Flora in Castile \& Leon (henceforth DFPCyL, ANON., 2007).

\section{RESULTS AND DISCUSSION}

Cosentinia vellea (Aiton) Tod.

Salamanca: La Fregeneda, the descent to Muelle de Vegaterrón, the Valdaslajas road, banks

* Evolution, Taxonomy and Conservation Group (ECOMED). Departamento de Botánica. Universidad de Salamanca. E-37005 Salamanca, Spain. Email: pacoamich@gmail.com 
of the River Águeda, 29TPF7541,210 m, narrow crevices on highly insolated gneisses, 16.02.2013, Amich, Rico \& Sánchez, SALA 146307; íbidem, 29TPF7541, $205 \mathrm{~m}$, narrow fissures on highly insolated gneisses, 07.03.2014, Amich \& RamírezRodríguez, SALA 149926.

This is a new locality for this Mediterranean palaoelement that must be added to the few known in western central Iberia (AMICH \& BERNARDOS, 2013), where the plant is very infrequent and with very few specimens in the Spanish populations. As in other localities where it is present, it is integrated in Mediterranean pteridophyte chasmophyte communities belonging the association Cheilantho maderensis-Cosentinietum velleae (Tabla 1, rels. 1-2), a finicolous association

Table 1

Relevés collected in the study area

Cheilantho maderensis-Cosentinietum velleae (1-2)

Adiantion capilli-veneris (3-4)

Phagnalo saxatilis-Antirrhinetum lopesianii (5-6)

\begin{tabular}{lcccccc}
\hline Altitude $(1=10 \mathrm{~m})$ & 20 & 20 & 49 & 38 & 49 & 38 \\
\hline Exposure & $\mathrm{SW}$ & $\mathrm{SW}$ & $\mathrm{N}$ & $\mathrm{NW}$ & $\mathrm{N}$ & $\mathrm{N}$ \\
Inclination $(\%)$ & 75 & 75 & 90 & 90 & 80 & 70 \\
Area $\left(\mathrm{m}^{2}\right)$ & 15 & 15 & 12 & 10 & 12 & 1 \\
Cover $(\%)$ & 15 & 25 & 12 & 10 & 70 & 50 \\
Relevé number & 1 & 2 & 3 & 4 & 5 & 6
\end{tabular}

Characteristics

Cosentinia velleae

Phagnalon saxatile

Rumex induratus

Anarrhinum bellidifolium

Adiantum capillus-veneris

Antirrhinum lopesianum

Dianthus lusitanus

Linaria saxatilis

Scrophularia valdesii

Companions

Sedum album

Umbilicus rupestris

Cheilanthes tinaei

Arrhenaterum elatius

Brachypodium dystachium

Euphorbia segetalis

Linaria amethystea

Targionia hypophylla

Ficus carica

Geranium lucidum

Milium vernale

Homalothecium sericeum

Annogramma leptophylla

Parietaria lusitanica

\begin{tabular}{|c|c|c|c|c|c|}
\hline 4 & 1 & . & . & . & . \\
\hline 2 & 2 & . & . & 2 & . \\
\hline+ & 1 & . & . & . & . \\
\hline+ & + & . & . & + & . \\
\hline . & . & 2 & 1 & . & . \\
\hline . & . & . & . & 2 & 1 \\
\hline$\cdot$ & $\cdot$ & . & . & 1 & . \\
\hline . & . & . & . & 1 & + \\
\hline$\cdot$ & $\cdot$ & . & . & . & 2 \\
\hline 2 & 3 & . & . & . & \\
\hline+ & + & . & . & + & 1 \\
\hline . & 3 & . & . & . & . \\
\hline . & 1 & . & . & . & . \\
\hline 1 & . & . & . & . & . \\
\hline+ & . & . & . & . & . \\
\hline+ & . & . & . & . & . \\
\hline 1 & 1 & . & . & . & . \\
\hline . & . & + & + & . & . \\
\hline . & . & + & + & . & + \\
\hline$\cdot$ & . & + & . & . & . \\
\hline . & . & + & + & . & . \\
\hline$\cdot$ & . & + & + & . & . \\
\hline . & . & . & . & 1 & 1 \\
\hline
\end{tabular}

Localities: All relevés from Salamanca (Spain). 1, 2: La Fregeneda, coming down to Muelle de Vegaterrón, Valdaslajas road, Águeda riverbank, 29TPF7541,07.03.2014; 3: Masueco de la Ribera, Arroyo de los Vasos, Cola de Caballo, Uces riverbank, 29TQF0267, 22.04.2014; 4: Aldeadávila de la Ribera, Playa del Rostro, Duero riverbank, 29TQF0068, 03.05.2014; 5: Masueco de la Ribera, Arroyo de los Vasos, Cola de Caballo, Uces riverbank, 29TQF0267, 22.04.2014; 6: Aldeadávila de la Ribera, Rupurupay, Duero riverbank, 29TPF9868, 22.04.2014. 
in these territories (AMICH \& BERNARDOS, 2013). It is necessary to search for new populations of this pteridophyte in Las Arribes del Duero, and it would be wise to establish conservation priorities for it, in view of its scarcity and the different threats these few populations are subject. It should also be included in the DFPCyL.

\section{Adiantum capillus-veneris L.}

Salamanca: Masueco de la Ribera, Arroyo de los Vasos, Cola de Caballo, banks of the Uces river, 29TQF0267, $495 \mathrm{~m}$, on rock cliff waters containing dissolved bases, 22.04.2014, Amich \& Ramírez-Rodríguez, SALA 151178; Aldeadávila de la Ribera, Playa del Rostro, Banks of the Duero river, 29TQF0068, $385 \mathrm{~m}$, on humid, shaded rock cliffs, 03.05.2014, Amich \& RamírezRodríguez, SALA 150901.

These are two new localities to be added to the two already known in the province of Salamanca (CASASECA \& al., 1982), one of which corresponded to the Natural Park of the Arribes del Duero, in particular to the Aldeadávila dam (AмICH, 1979). At this locality, Adiantum appeared on the mortar of the human dwellings at the Dam, but the small population existing then is no longer present.

We have now found two new populations to the north of the Dam, one on the banks of the Duero River and the other on the banks of one of its affluents, the Uces. In both cases the species lives on the rock faces of Ordovician gneisses with carbonated intercalations characteristic of the territory (RODRÍGUEZ-ALONSO \& al., 2004). In drier zones, these rock faces feature a characteristic vegetation corresponding to the endemic association Phagnalo saxatilis-Antirrhinetum lopesianii, whereas in moister, oozing areas there are chasmophyte communities typical of rock formations periodically flooded by water containing calcium carbonate corresponding to the alliance Adiantion capilli-veneris (Table 1, rels. 3-4). As in the case of Cosentinia, "culantrillo de pozo" (maidenhair fern) is an extremely rare plant in central-western Spain, with a low number of individuals in the two known populations in the Park, and is strongly threatened owing to the decline in rainfall and noteworthy drying-up of small water-courses that allow water to flow across the gneissic rock faces. Again, it would be appropriate to include some conservation priorities for the maidenhair fern.

Delphinium fissum subsp. sordidum (Cuatrec.) Amich, E.Rico \& J. Sánchez.

Salamanca: Aldeadávila de la Ribera, Los Ceños, way down to Playa del El Rostro, 29TQF0168, 480 $\mathrm{m}$, grassy patches with gall-oaks and holm-oaks, Galio-Alliarion communities, 08.07.2014, Amich \& Ramírez-Rodríguez, SALA 152998.

A restricted endemism of the central-western Iberian Peninsula, with a distant population in the Mágina range (Jaén) (Blanché, 1985, MATEO \& PISCO, 1993), that is included in the RL2008 Red Book) under the category of "endangered" and in Annex I of the DFPCyL as "in danger of extinction". In CW Spain it has several disperse populations, comparatively separated from one another, and, with the exception of a population at Villarino de los Aires (Salamanca), all have a very reduced number of individuals (RAMíREZRODRÍGUEZ \& al., unpub. data). Accordingly, from a demographic point of view one of the new populations located in the area known as "Los Ceños" seems to be relevant, since it contains a relatively high number of individuals, 58, of which 17 were reproducing individuals in the summer of 2014. This new location and the size of the population should allow us to carry out new demographic studies, together with those we have been carrying out on the population at Villarino (RAMÍREZ-RODRÍGUEZ \& al., unpub. data).

The small population sizes, the low number of populations, and their reduced genetic diversity (ORELlana \& al., 2007) reflect a trend towards extinction if no conservation strategies are implemented. Thus, we believe that there is an urgent need for a Recovery Plan for this species in Castile \& León.

Antirrhinum lopesianum Rothm.

Salamanca: Masueco de la Ribera, Arroyo de los Vasos, Cola de Caballo, Uces riverbanks, 
29TQF0267, $495 \mathrm{~m}$, gneiss wall rock crevices, 22.04.2014, Amich \& Ramírez-Rodríguez SALA 151177, Aldeadávila de la Ribera, Rupurupay, banks of the River Duero, 29TPF9868, 380 m, gneiss wall rock crevices, 22.04.2014, Amich \& Ramírez-Rodríguez SALA 151174.

An endemism of the Lusitanian-Durian biogeographic sector (CW Spain and NE of Portugal) (BERNARDOS \& al., 2006b) included in the RL2008 under the category of "Endangered" and in Annex I of the DFPCyL as a plant "in danger of extinction". Here we report a new subpopulation, with a total of 178 individuals, very close to that reported by BERNARDOS \& al. (2004a) at Aldeadávila de La Ribera. All the foregoing seems to indicate that between both sets of individuals there is a substantial genetic flow. The whole of the metapopulation would consist of 641 specimens, such that it would be the population with the greatest number of specimens of A. lopesianum of all those known, both in Spain and in Portugal (Bernardos \& al., 2006b).

We also describe a new location, on the banks of the River Uces, also with an important number of individuals (100) and under reasonably good conditions of conservation, despite being next to a hiking path subject to considerable human activity (hiking) in the spring, the time of year that coincides with the spectacular flowering of the "Dragón de Las Arribes". As in the case of Delphinium, we believe in the urgent need for a Recovery Plan, or at least a Conservation Plan, for this species in Castile \& Leon.

It is included in the Lusitan-Duriensean synendemism Phagnalo saxatilis-Antirrhinetum lopesianii (Table 1, rels. 5-6), which is found on the rock faces of Ordovician gneisses with carbonated intercalations typical of the territory.

Scrophularia valdesii Ortega Olivencia \& Devesa

Salamanca: Aldeadávila de la Ribera, Rupurupay, Duero riverbanks, 29TPF9868, $385 \mathrm{~m}$, on gneiss rock cliff broad crevices, 22.04.2014, Amich \& Ramírez-Rodríguez, SALA 151175.
This is an endemism restricted to the lower basin of the River Duero (Arribes del Duero) (BERnardos \& al., 2006a), included in the RL2008 under the category of "Vulnerable" and in Annex I of the DFPCyL, also as "Vulnerable". We report a new population to be added to the few known to date (BERNARDOS \& al., 2006a). This population has a low number of specimens (less than a dozen), as is the case of most of the known populations. Threats due to human activities in the area are highly unlikely owing to the difficult access to the location where the plant is found. Like the previous species, it is characteristic of the endemic association Phagnalo-Antirrhinetum lopesianii (Table 1, rel. 6).

\section{Barlia robertiana (Loisel.) Greuter.}

Salamanca: Aldeadávila de la Ribera, Rupurupay, Duero riverbanks, 29TPF9868, $380 \mathrm{~m}$, humid patches at the bases of ridges, amongst hackberry (Celtis australis) stands and thermophile oaks, 22.04.2014, Amich \& Ramírez-Rodríguez, SALA 151180.

A very rare and scarce orchid in the province of Salamanca and CW Spain, with only three localities known to date in Salamanca (BERNARDOS \& AMICH., 2000, BERNARDOS \& al., 2006c), and is included in Annex II of the DFPCyL as a taxon 'of preferential attention'. Only the population present at Muelle de Vegaterrón, at La Fregeneda, has an appreciable number of specimens, ranging between 50 and 150 in recent years, while the population at the Aldeadávila dam ranges between 15 and 20 specimens, and the small population present at the Playa del Rostro, at Corporario, can be considered to have disappeared since it has not been seen again in the last three years. This is probably due to intense anthropic activities in the area owing to the presence of hikers, boat trips on the river, etc. Here we report a new population, also with a reduced number of individuals (13), although the inaccessibility of the zone where it is found, which can only be reached on a launch on the River Duero, means that in this case it is protected from human activity. Although Barlia is integrated in the territories of the Park mainly 
in the association Lavandulo sampaianae-Cistetum albidi, it is also found in humid patches attributable to the alliance Galio aparines-Alliarion petiolatae.

\section{ACKNOWLEDGEMENTS}

We thank Daniel Pinto for his indications to find the population of Antirrhinum lopesianum on the banks of the River Uces.

\section{REFERENCES}

Amich, F. - 1979- Estudio de la flora y vegetación de la comarca de Vitigudino - Mem. Doc. (inéd.). Univ. Salamanca. 334 pp.

Amich, F. \& Bernardos, S. -2013- Las fitocenosis de Cosentinia vellea en el sector biogeográfico Lusitano Duriense (España-Portugal) - Bot. Compl. 37: 93-98.

Amich, F., Bernardos, S., Aguiar, C., Fernández-Diez, F.J., \& Crespí, A.L. -2004- Taxonomic composition and ecological characteristics of the endemic flora of the lower Duero Basin (Iberian Peninsula) - Acta Bot. Gallica 151: 341-352.

Anonymous -2007 - Decreto 63/2007, de 14 de junio, por el que se crean el Catálogo de Fklora Protegida de Castilla y León y la figura de protección denominada Microreserva de Flora - Bol. Of. Castilla y León 119: 13197-13204.

Bernardos, S., \& Amich, F. - 2000 - Novedades y comentarios para la orquidoflora centro-occidental ibérica Lazaroa 21: 13-18.

Bernardos, S., Amado, A. \& Amich, F. -2006a- The narrow endemic Scrophularia valdesii Ortega-Olivencia \& Devesa (Scrophulariaceae) in the Iberian Peninsula: an evaluation of its conservation status - Biod. Cons. 15: 4027-4043.

Bernardos, S., Amado, A., Aguiar, C., Crespí, A., Castro, A. \& Amich, F. -2004a- Aportaciones al conocimiento de la flora y vegetación del centro-occidente ibérico (CW de España y NE de Portugal) - Acta Bot. Malacitana 29: 292-293.

Bernardos, S., Amado, A., Aguiar, C., Santos, C., FernándezDíez, F.J., González-Talaván, A. \& Amich, F. -2006bConservation status of the threatened Iberian Peninsula narrow endemic Antirrhinum lopesianum Rothm. (Scrophulariaceae) - Plant Biosyst. 140: 2-9.

Bernardos, S., Crespí, A., Aguiar, C., Fernández-Diez, F.J. \& Amich, F. - 2004b- The plant communities of the Rumici indurati-Dianthion lusitani in the Lusitan Duriensean biogeographical sector (NE Portugal and CW Spain) - Acta Bot. Gallica 151: 147-164.

Bernardos, S., Tyteca, D., García-Barriuso, M., Crespí, A.L., Castro, A. \& Amich, F. - 2006c-Current status and conservation of the Lusitan Duriensean orchids (Duero Basin, NE Portugal and CW Spain) - Acta Bot. Gallica 153: $273-284$
Blanché, C. - 1985 - Una nova localitat de Delphinium fissum Waldst. \& Kit. subsp. sordidum (Cuatrec.) Amich, Rico \& Sánchez. Comentari sobre la seva distribució - Collect. Bot. 16: 230-231.

Casaseca, B., Fernández-Diez, F.J., Amich, F., Rico, E., Sánchez, J. -1982- Catálogo de las plantas vasculares de la provincia de Salamanca. I. Pteridophyta - Trab. Dep. Bot. Salamanca 10: 5-27.

Castroviejo, S. \& al. (Eds.) - 1986-2010 - Flora iberica R. Jard. Bot. Madrid, C.S.I.C., Madrid.

Costa, J.C., Neto, C., Aguiar, C., Capelo, J., Espírito Santo, M.D., Honrado, J., Pinto-Gomes, C., Monteiro-Henriques, T., Sequeira, M. \& Lousã, M. -2012- Vascular plant communities in Portugal (continental, the Azores and Madeira - Global Geobot. 2: 1-180.

González, J.A., García-Barriuso, M., Ramírez-Rodríguez, R., Bernardos, S. \& Amich, F. - 2012- Plants used in folk cosmetics and hygiene in the Arribes del Duero Natural Park (western Spain) - Lazaroa 33: 9-18.

Mateo, G. \& Pisco, J.M. - 1993- Delphinium fissum subsp. sordidum (Cuatrec.) Amich, Rico \& Sánchez en el Sistema Ibérico - Acta Bot. Malacitana 18: 286-287.

Moreno, J.C. (Coord.). -2008 - Lista Roja 2008 de la Flora Vascular Española - Dir. Gen. Medio Nat. Pol. For., Min. Medio Amb. Madrid. 86 pp.

Orellana, M.R., López-Pujol, J., Blanché, C. \& Bosch, M. $-2007-$ Genetic diversity in the endangered dysploid larkspur Delphinium bolosii and its close diploid relatives in the series Fissa of the Western Mediterranean area - Biol. J. Lin. Soc. 92: 773-784.

Rivas-Martínez, S. - 2011 - Mapa de series, geoseries y geopermaseries de Vegetación de España - Itinera Geobot. 18: 5-800.

Rivas-Martínez, S., Díaz, T.E., Fernández-González, F., Izco, J., Loidi, J., Lousa, M. \& Penas, A. - 2002 - Vascular plant communities of Spain and Portugal - Itinera Geobot. 15: 5-922.

Rodríguez-Alonso, M.D., Peinado, M., López-Plaza, M., Franco, P., Carnicero, A. \& Gonzalo, J.C. - 2004- Neoproterozoic-Cambrian synsedimentary magmatism in the Central Iberian Zone (Spain): geology, petrology and geodynamic significance - Int. J. Earth Sci. 93: 897920 


\section{APPENDIX}

Communities cited in the text by alphabetical order:

Adiantion capilli-veneris Br.-B1. ex Horvatic 1934

Cheilantho maderensis-Cosentinietum velleae Ladero ex F.J. Pérez, T.E. Díaz, P. Fernández \& Salvo 1989

Galio aparines-Alliarion petiolatae Oberdorfer \& Lohmeyer in Oberdorfer, Görs, Korneck, Lohmeyer, Müller, Philippi \& Seibert 1967

Genisto hystricis-Quercetum rotundifoliae P. Silva 1970

Junipero lagunae-Quercetum suberis Rivas-Martínez, Aguiar, Cantó \& Ladero 2002

Lavandulo sampaianae-Cistetum albidi M.T. Santos 1987

Phagnalo saxatilis-Antirrhinetum lopesianii Bernardos, Crespí, Aguiar, F.J. Fernández \& Amich 2004

Rusco aculeati-Juniperetum lagunae (J.C. Costa, Capelo, Lousã \& Aguiar 1993) Aguiar et al. 2003 